\title{
EDITORIAL: REPELLENT MUSIC
}

\author{
Christopher Fox
}

Summer is the silly season for news. In August 2018 Deutsche Bahn, the German railway company that also runs Berlin's S-Bahn system, announced that it had come up with a way of deterring the 'junkies and drunks' who hang around the Hermannstrasse S-Bahn station in the Neukölln district of the city. Because these vagrants were spoiling the 'customer experience' for passengers they needed to be driven out of the station, off the platforms, the stairs, the walkways.

How to do this? Deutsche Bahn had already tried to do something similar at the main railway station in Hamburg by playing classical music. It's a practice with a precedent, first tried in Montreal in the 1990 s, then on the Tyne and Wear metro and, ten years ago, in a number of London underground stations. Feedback in London suggested that for passengers hearing classical music made them feel happy, less stressed and relaxed' and, perhaps because it was not the music they would have chosen themselves, encouraged people who were using the stations as a temporary home to move on.

On the London underground the choice of music was originally subcontracted to a company that created a 40 -hour playlist of 'tuneful' music, mostly from the eighteenth and nineteenth centuries; but with repulsion rather than relaxation in mind the S-Bahn authorities planned to flood the Hermannstrasse station with 'atonal' music, which they described as music 'to run away from'. The Deutsche Bahn press release offered nothing more specific about repertoire, so we can only speculate about how they defined atonality. What is more interesting is their belief that there is a type of music more likely than any other to keep people on the move, a type of music that people wouldn't want to hear if they could possibly avoid it.

Even more interesting is what happened next. Deutsche Bahn's declared intention was to launch the atonal offensive in September 2018 but as the news began to circulate there was an immediate reaction from musicians in Berlin. The organisation Initiative Neue Musik Berlin posted plans for an event, 'Atonale Musik für alle', on their Facebook page and on 24 August several hundred people gathered at the entrance to the Hermannstrasse S-Bahn to listen to improvised music and compositions by Sciarrino, Juliana Hodkinson and Julius Eastman. Deutsche Bahn have subsequently decided not to go ahead with their scheme.

It's tempting to draw conclusions, but the more I have thought about Deutsche Bahn's plans and their repercussions the less sure I am about what these conclusions might be. Certainly it was striking how quickly and effectively the 'Atonale Musik für alle' event came together but does this mean that there is a universal fondness for new music? Or was the audience of 300 (as reported by neue musikzeitung) made up of people who, on a warm Friday evening in August, thought it would be fun to meet up with colleagues after the summer holidays? Would the same thing happen in other major cities or is Berlin, for so many years a haven for progressive artists, an exceptional 
place? How much did the success of the event depend on Initiative Neue Musik Berlin's well-established networks?

What about the use of music as a weapon? It's easy to condemn large corporations for their crass abuse of music, whether it's the appropriation of tunes for TV advertising or the wallpapering of particular environments to encourage 'dwell-time' or, as was proposed for the Hermannstrasse S-Bahn, non-dwell-time. But most cultures and sub-cultures use music as part of a way of marking territory, an activity that frequently tips over into markedly more aggressive behaviour, from football chants to tunes for marching. One might even argue that everyone who wears headphones as they move through a shared social space is creating an exclusion zone around themselves, a fairly passive form of resistance but resistance nonetheless.

Finally there are the questions raised by Deutsche Bahn's view that 'atonal' music is 'something to run away from'. What is 'atonal' music anyway? Would Schoenberg's String Trio shift vagrants more quickly than Ferneyhough's? More seriously, why should the experience of listening to music always be comfortable? The history of the world is full of artefacts - visual, aural, narrative, olfactory - that were designed to be shocking and our musical lives would be utterly impoverished if all our listening was 'easy'

A silly season story perhaps and, in the end, one that isn't really about music at all. We live in societies where if you are poor and addicted to drugs you cease to be a person. Instead you become a problem and the simplest thing to do with a problem is to move it somewhere else. That's what Deutsche Bahn was planning to do. 'Atonale Musik für alle' is an unlikely rallying call with which to launch a programme for social inclusion, but it's better than running away. 